\title{
Leadership Connection to Emotional Intelligence and Stress at Workplace
}

\author{
Nadeem Ahmad Bashir \\ Department of Management, College of Business Administration, \\ King Saud University, Saudi Arabia \\ E-mail: drnab1965@hotmail.com
}

Received: April 18, 2016

Accepted: Nov. 20, 2016

Published: January 1, 2017

doi:10.5296/jmr.v9i1.9338

URL: http://dx.doi.org/10.5296/jmr.v9i1.9338

\begin{abstract}
Emotional intelligence has gained huge attention of practitioners and researchers over the last decade. This paper aims to highlight the relatively less focused, but the key domain of stress at work and its linkage with the emotional intelligence of leadership. Based on previous studies, this study accumulated the issues regarding emotional intelligence of leadership and its capacity to handle the stress more effectively. Though intelligence quotient is necessary for leaders, emotional intelligence of leadership is identified as most significant to cope with stress at work and create a healthy work environment. Specifically, the level of leaders' emotional intelligence sets for how subordinates respond, to perform more effectively at different stressful circumstances.
\end{abstract}

Keywords: Emotional intelligence, Leadership, stress, workplace 


\section{Introduction}

Present century is an era of speed, the information revolution and globalization (Cascio, 2001). Businesses are directly affected by these changes as organizations are restructuring, modernizing the strategies and updating the technologies (Langley, 2000). In this scenario, new roles and duties have been imposed on leadership by the organizations. Such changes and additional responsibilities have created stress at work.

This stress is not only affecting work qualities, but also personal life. Leaders' intelligence quotient (IQ) and emotional quotient (EQ) are becoming more significant in the problem-solving and decision-making process. Sirin (2007) argued that individuals can deal with stress through intelligence and emotional intelligence (EI).Researchers have diverse views of intelligence and emotional intelligence. A number of researchers believe that intellectual intelligence and emotional intelligence are two dissimilar concepts with opposite features (Stein \& Book, 2003; Halicinarli \& Bender, 2006), while many studies have argued that emotional intelligence is possibly the most refined feature of intelligence (Shapiro, 2004). Emotional intelligence for leaders becomes noteworthy for leaders with the support of findings that emotional intelligence is superior in intellectual intelligence, as cognitive resources (emotion, motivation and desire)are required as inputs of problem solving (Erdogdu, 2008).

There are abundant studies on the topic of emotional intelligence of leadership and its effect on followers, including stress, but only few researches available to examine the effect of leaders' emotional intelligence on their stress level. Researchers have stated that emotional intelligence of individuals is useful to understand and manage their emotions, to be adaptable in their surroundings, and enhance the tolerance level of stress (Kalyoncu, Guney, Arslan, Guney, \& Ayranci, 2012; Matthews et al., 2006; Goleman, 1995). According to Ucar (2004), emotional intelligence has the ability to play a vital role in determining the source of the stress through the mental process. The answer to the question that how stress reduces the mental ability can be found by the findings of Baltas and Baltas (2008) that some fraction of mental capacity is fixed to deal with the stress level. This study highlighted the importance of emotional intelligence-stress relationship in the workplace and emphasizes its connection with leadership.

\section{Emotional Intelligence}

Intelligence generally refers to cognitive ability, also known as intelligence quotient. Intelligence has been commonly used in businesses for employee selection. Initially, intelligence was supposed to be fixed at birth, but presently, there is an ongoing debate on its genetic connection (Cooper, 2012; Sternberg, 2011). Gardner (1983) developed seven multiple intelligences (MIs); mathematical/logical, verbal/linguistic, intrapersonal, interpersonal, visual, bodily and musical in a famous book, Frames of Mind. MIS theory mainly stated that intelligence can be developed rather than be genetic.

Researchers have ongoing interest in emotional intelligence as various definitions of emotional intelligence are presented. Salovey and Mayer (1990) were the first to formally 
identify the term Emotional Intelligence and define it as the subset of social intelligence that includes one's ability to monitor oneself and feelings and emotions of others, to differentiate among them and ability to use this information to direct one's actions. Later, Goleman (1995) defined emotional intelligence asthe ability of individuals to understand one's emotions, manage them, motivate one's self, recognize emotions in others, and manage relationships with others (Goleman, 1995). Goleman (1995)claimed that in the workplace, main dimensions of emotional intelligence are self-awareness, self-motivation, self-management, relationship management and social awareness. Goleman's (1998) model of emotional intelligence was refined by Boyatzis et al (2000) into four dimensions; self-awareness, self-management, social awareness and relationship management.

\section{Self-awareness}

Self-awareness has been considered as the most significant dimension (Goleman, 1996; Bar-On, 1997). Goleman (1996) argued that self-awareness as knowing one's emotions and recognizing a feeling is the basis of emotional intelligence. Knowing internal states of emotions help in self-control, which is needed for leaders for empathy in others.

\section{Self-management}

Self-management refers to the ability to deal with own feelings in a proper way. Goleman (1996) claimed that individuals with high self-management ability can handle with stress and solve the problems much better than those who are poor in self-management. Thus, self-management of emotions helps in controlling the anxiety and anger for higher productivity.

\section{Social awareness}

The ability of individuals to know how to feelor recognize emotions in others is known as social awareness. Goleman (1996) argued that self-awareness contributes in reading the feelings of others as people cannot know what others around are feeling without knowing oneself. This is an ability to understand what is going on around by correctly feeling the emotions of other people.

\section{Relationship management}

The skill of managing emotions in others is known as relationship management. Goleman (1996) stated that emotionally adept people are more successful in multi spheres of life and organizational politics by knowing and managing their own feelings, and effectively dealing with people's feelings. Relationship management is the ability to use self-awareness of emotions and the emotions of others to manage relations successfully through effective communication (Bradberry \& Greaves, 2002).

\section{Stress}

The focus of this study is on stress, in addition to emotional intelligence. Nowadays, stiff competition and the concept of change is very common in all fields, which is leading to stress at work. Though stress is an old concept, researchers have started studying the concept of 
stress science and emphasize to study stress as an interdisciplinary subject (Ozbay \& Senyuz, 1998). Origin of the word "stress" belongs to a Latin verb "estrica", and refers to applying force and pressure since the 18th century (Guney, 2000). Stress has been used in various science branches (Agma, 2007). Cuceoglu (1999) referred stress as individual's as effort of individuals that exceed one's psychological and physical capacity in response to unsuitable working environment. However, Selye (1985) stressed on psychological and physiological viewpoint and defined stress as the reaction of body against any common demand loaded on it. Rogers (2007) linked stress with tension and explained as a tensed situation based on factors including conflict, inhibition, change and specific individual elements. Stress is not always a negative term as a recent research found that individuals need to maintain a specific stress level for efficiency and better productivity (Sahin, 2010).

\section{Emotional Intelligence of Leadership and Stress}

Various researchers have worked to identify the determinants of leadership, and agree on a common set of abilities which are empathy, motivating power, intuitive ability and integrity which are the part of emotional intelligence abilities to manage self and interaction with others(Goleman, Boyzatzis, \& McKee, 2002).IQ and emotional intelligence are two different concepts and are independent of each other (Goleman et al., 2002). Though a leader need to have sufficient intelligence to understand the contemporary issues and clear vision, but super smartness is not required. Being intellectually gifted is not a guarantee to be a successful leader. Many organizations that focus on IQ skills for employee promotions rather than the emotional intelligence abilities of good leaders, mostly fail and disqualify their decisions.

Leadership is generally regarded as highly stressful. A famous psychologist, Levinson (1981) reflected this opinion in words, "managing others ... creates unending stress ... Today's managers face increasing time pressures with little respite" (p. 77). Managers high in EI are found to have better psychological and physical well-being, better able to deal with subjective stress, and exhibit better in role job performance than those low in EI (Slaski \& Catwright, 2002). Thus, leader's stress management has become a point of focus and number of psychologists and social scientists has suggested tools to assist leaders in managing stress. Research conducted in the domain of nursing have confirmed that emotional intelligence positively impacts leadership and the ability to deal with stress (Akerjordet \& Severinson, 2008; Montes-Berges \& Augusto, 2007).Research suggests that leaders with high levels of EI experience more career success and with effective leadership (Rosete \& Ciarrochi 2005;Dulewicz \& Higgs, 2003), feel more job security (Jordan et al., 2002) are more adaptable to stressful events (Nikolaou \& Tsaousis, 2002; Slaski \& Cartwright, 2002) than those with low EI.

Additionally, a positive relationship was found between EI and leadership style including, transformational leadership and charismatic leadership(Prati, Douglas, Ferris, Ammeter, \& Buckley (2003) and transformational leadership is better able to deal with stress (Downey, Papageorgiou, \& Stough, 2006). According to Downey et al. (2006), female leaders who are perceived to be more transformational in their leadership style also described as being able to understand the self-feelings and emotions, to demonstrate inner feelings to others, to 
understand the emotions of others, use emotions in problem solving, and effectively manage emotional feelings at work including stress, anxiety and anger (Downey et al., 2006).Transformational leadership and charismatic leadership, both encompass emotional skills abilities of idealized influence and inspirational motivation. Our argument is that leaders have an emotional relationship with followers, and EI of leaders can affect the leader-member exchange relationship quality (Dasborough \& Ashkanasy, 2002).

Moreover, leaders are the primary source of feedback to the employees. However, employees' satisfaction with feedback is important to increase the performance (Rasheed, Rehman, Rasheed, \& Munir, 2015). Therefore, leader emotional intelligence may be more important than in others to create a supportive feedback environment (Dahling, Chau, \& O’Mally, 2012), in a highly stressful work situation (Salas, Driskell, \& Hughs, 1996). We also know that supervisor feedback environment has a significant negative relationship with stress at work and job burnout (Peng \& Chiu, 2010).

\section{Discussion}

Conventionally, intelligence was known as cognitive mental ability. Later, the concept of multiple intelligences was introduced in this narrow perspective. The climate of the organization is the outcome of the behaviors, decision-making abilities, communication efforts, emotions, leadership style and conduct of the leader. A new domain of intelligence was added into discussion by Daniel Goleman, known as emotional intelligence. Goleman (2004) stated that leader generates the conditions that directly regulate people's capability to work well and execute their tasks within the organization. The emotional intelligent leader can direct more efficiently and create a workplace that strengthens high performance and produce significantly impact on the financial results of the organization. The emotional intelligence of the leader is significant for the effective working of the team. The leader performs a role as a motivator in the direction of collective action, and assists helpful relations among team members (Prati et al., 2003). The leaders who have emotional intelligence at work have the potential to provide a transformational effect over their team members. This positive behavior can be transformed by providing team standards, legitimizing team members, and charisma of inspiring team identity and pride to enhance effective functioning of the organization.

\section{Conclusion}

For the last two decades, emotional intelligence has become a point of attention, mainly related to leadership. Empirical findings have confirmed that the dimensions of EI (self-emotional awareness, others' emotional awareness, self-management, social awareness, and relationship management) may have a better effect on leadership effectiveness with successful coping with stress at work than the traditional IQ. Previous studies revealed that emotional intelligence was significant in social situations, IQ is vital in cognitive tasks (Offermann, Bailey, Vasilopoulos, Seal, \& Sass, 2004; Jordan \& Troth, 2004). No doubt, IQ is a critical and key ingredient of leadership, based on evidence we suggest that emotional intelligence is more important for leaders in different contexts, including stress at work than general intelligence. Judge, Colbert, \& Ilies (2004) argued in the same line and enlisted 
principles of cognitive resource theory that in stressful situations, leader's cognitive intelligence becomes less relevant, while other non-cognitive abilities come to be more salient. Thus, emotional intelligence qualifies leaders to deal with stressful settings, and general intelligence can be resumed as soon as the leader has dealt with the stressful environment.

\section{References}

Agma, F. Ş. (2007). The negative effects and reasons of stress in work life (In Turkish). Master's thesis, At1lım University, Ankara, Turkey.

Akerjordet, K., \& Severinson, E. (2008). Emotionally intelligent nurse leadership: a literature review study. $J \quad$ Nurs Manag, 16(5), 565-577. https://doi.org/10.1111/j.1365-2834.2008.00893.x

Baltas, A., \& Baltaş, Z. (2008). Stress and the ways to cope with it. Remzi Publications, İstanbul, Turkey.

Bar-On, R. (1997). Bar On Emotional Quotient Inventory Technical Manual. MHS Publications, Toronto.

Boyatzis, R. E., Goleman, D., \& Rhee, K.S. (2000). "Clustering competence in emotional intelligence", in Bar - On, R. and Parker, J.D.A. (Eds), Handbook of Emotional Intelligence, Jossey - Bass, San Francisco, CA, pp. 343 - 62.

Bradberry, T., \& Greaves, J. (2002). Emotional Intelligence Appraisal: There is more than IQ, Me Edition.

Cascio, W. F. (2001). Knowledge creation for practical solutions appropriate to a changing world of work. South African Journal of Industrial Psychology, 27(4), 14-16. https://doi.org/10.4102/sajip.v27i4.798

Cooper, C. (2012). Intelligence and abilities. New York, NY: Taylor \& Francis.

Cuceloglu, D. (1999). Human and behavior, basic concepts of psychology (In Turkish). Remzi Publications, İstanbul.

Darling, J. J., Chau, S. L., \& O'Malley, A. (2012). Correlates and Consequences of Feedback Orientation in Organizations. Journal of Management, 38(2), 531-546. https://doi.org/10.1177/0149206310375467

Dasborough, M. T., \& Ashkanasy, N. M. (2002). Emotion and attribution of intentionality in leader-member relationships. The Leadership Quarterly, 13(5), 615-634. https://doi.org/10.1016/S1048-9843(02)00147-9

Downey, L. A., Papageorgiou, V., \& Stough, C. (2006). Examining the relationship between leadership, emotional intelligence and intuition in senior female managers. Leadership \& Organization Development Journal, 250-264. https://doi.org/10.1108/01437730610666019 
Dulewicz, V., \& Higgs, M. (2003). Leadership at the top: The need for emotional intelligence in organizations. The International Journal of Organizational Analysis, 11(3), 193-210. https://doi.org/10.1108/eb028971

Erdogdu, M. Y. (2008). An analysis of emotional intelligence via some variables (In Turkish). Electronic Social Sciences Journal, 7(23), 62-76.

Gardner, H. (1983). Frames of mind: The theory of multiple intelligences. New York, NY: Basic Books.

Goleman, D. (1995). Emotional Intelligence: Why it can Matter more than IQ, Bantam, New York, NY.

Goleman, D. (1996). Emotional Intelligence: Why It Can Matter More than IQ, Bloomsbury Publishing, London.

Goleman, D., Boyzatzis, R., \& McKee, A. (2002). Harvard Business Review on what makes a leader. Boston, MA: Harvard Business School Press.

Guney, S. (2000). Behavioral sciences (In Turkish). Nobel Publications, Ankara Turkey.

Halicinarli, E., \& Bender, M. T. (2006). Emotional intelligence (EQ) of women and a field research (In Turkish). Paper presented at the Second International Conference on Women's Studies, 27-28 April 2006, Northern Cyprus.

Jordan, P. J., \& Troth, A. C. (2004). Managing emotions during team problem solving: Emotional intelligence and conflict resolution. Human performance, 17(2), 195-218. https://doi.org/10.1207/s15327043hup1702_4

Judge, T. A., Colbert, A. E., \& Ilies, R. (2004). A meta-analysis of the relationship between intelligence and leadership. Journal of Applied Psychology, 89, 542-552. https://doi.org/10.1037/0021-9010.89.3.542

Kalyoncu, Z., Guney, S., Arslan, M., Guney, S., \& Ayranci, E. (2012). Analysis of the relationship between emotional intelligence and stress caused by organization: A study of nurses. Busi Intell J, 5(2), 334-346.

Langley, A. (2000). Emotional intelligence - a new evaluation for management development? Career Dev Int. 5(3), 177-183. https://doi.org/10.1108/13620430010371937

Levinson, H. (1981). When executives burn out. Harv Bus Rev, 59,73-81.

Matthews, G. Emo, A. K., Funke, G., Zeidner, M., Roberts, R. T., Costa, P. T., \& Schulze, R. (2006). Emotional intelligence, personality and task-induced stress. J Exp Psychol Appl. 12(2), 96-107. https://doi.org/10.1037/1076-898X.12.2.96

Montes-Berges, J., Augusto, B. M. (2007). Exploring the relationship between perceived emotional intelligence, coping, social support and mental health in nursing students. $J$ Psychiatr Ment Health Nurs, 163-171. https://doi.org/10.1111/j.1365-2850.2007.01059.x 
Nikolaou, I., \& Tsaousis, I. (2002). Emotional intelligence in the workplace: Exploring its effects on occupational stress and organizational commitment.The International Journal of Organizational Analysis, 10(4), 327-342. https://doi.org/10.1108/eb028956

Offermann, L. R., Bailey, J. R., Vasilopoulos, N. L., Seal, C., \& Sass, M. (2004). The relative contribution of emotional competence and cognitive ability to individual and team $\begin{array}{llll}\text { performance. Human } \quad \text { 219-243. } & \text { Performance, }\end{array}$ https://doi.org/10.1207/s15327043hup1702_5

Ozbay, Y., Senyuz, A. (1998). An analysis of perceived job satisfaction in different occupations and stress levels in relation to gender. Paper presented at the Tenth National Psychology Congress, 16-18 September 1998, Ankara, Turkey.

Peng, J., \& Chiu, S. (2010). An Integrative Model Linking Feedback Environment and Organizational Citizenship Behavior. The Journal of Social Psychology, 150(6), 582-607. https://doi.org/10.1080/00224540903365455

Prati, L. M. Douglas, C., Ferris, G. R., Ammeter, A. P, \& Buckley, M. R. (2003). The Role of Emotional Intelligence in Team Leadership: Reply to the Critique by Antonakis. The International Journal of Organizational Analysis, 11(4), 363-369. https://doi.org/10.1108/eb028981

Rasheed, A., Khan, S. U. R., Rasheed, M. F., \& Munir, Y. (2015). The Impact of Feedback Orientation and the Effect of Satisfaction With Feedback on In - Role Job Performance. Human Resource Development Quarterly, 26(1), 31-51. https://doi.org/10.1002/hrdq.21202

Rogers, A. K. (2007). Stress Perceptions in Occupational Therapy Students: Traditional versus Distance Education. Master's thesis, West Virginia University, Morgantown, WV.

Rosete, D., \& Ciarrochi, J. (2005). Emotional intelligence and its relationship to workplace performance outcomes of leadership effectiveness. Leadership \& Organization Development Journal, 26(5), 388-399. https://doi.org/10.1108/01437730510607871

Sahin, N. H. (2010). Finding your own "positive stress" level, coping up with stress: A positive approach (In Turkish). Turkish Psychologists Association Publications, Ankara, Turkey.

Salas, E., Driskell, J. E., \& Hughes, S. (1996). The study of stress and human performance. Stress and human performance, Mahwah, NJ, Lawrence Erlbaum Associates, Publishers, 1996, 1-45.

Salovey, P., \& Mayer, J. D. (1990). Emotional intelligence. Imagination, cognition and personality, 9(3), 185-211. https://doi.org/10.2190/DUGG-P24E-52WK-6CDG

Selye, H. (1985). The Stress of Life. Springer-Verlag, New York.

Shapiro, L. E. (2004). To raise a kid with high EQ (In Turkish). (Trans. by Ümran Kartal), Varlık Publications, İstanbul. 


\section{Macrothink}

Journal of Management Research

ISSN 1941-899X 2017, Vol. 9, No. 1

Sirin, G. (2007). The relationship between teachers' emotional intelligence levels and their ways of coping up with stress (In Turkish). Master's thesis, Gazi University, Ankara, Turkey.

Slaski, M., \& Cartwright, S. (2002). Health, performance and emotional intelligence: An exploratory study of retail managers. Stress and Health, 18, 63-68. https://doi.org/10.1002/smi.926

Stein, S. J., \& Book, H. E. (2003). EQ: The secret of emotional intelligence and success (In Turkish). Özgür Publications, İstanbul, Turkey.

Sternberg, R. J. (2011). The Cambridge handbook of intelligence. New York, NY: Cambridge University Press. https://doi.org/10.1017/CBO9780511977244

Ucar, F. (2004). The role of mind in stress, and cognitive and psychological disorders related to stress. Turkish Psychology Bulletin, 10(34-35), 85-102.

Prati, L., Ferris, D. C., Ammeter, A. P., \& Buckley, M. R. (2003). Emotional intelligence, leadership effectiveness, and team outcomes. International Journal of Organizational Analysis, 11, 21-40. https://doi.org/10.1108/eb028961 